\title{
Growth and Sexual Maturation of the American Sand Lance (Ammodytes americanus Dekay) off the North Shore of the Gulf of St. Lawrence
}

\author{
Jean-Claude F. Brêthes, Roger Saint-Pierre and Gaston Desrosiers \\ Centre océanographique de Rimouski, Université du Québec à Rimouski \\ 300, Allée des Ursulines, Rimouski, Québec, Canada G5L 3A1
}

\begin{abstract}
Samples of American sand lance (Ammodytes americanus) were collected in JuneSeptember 1983 off the north shore of the Gulf of St. Lawrence, at depths varying from 1 to $40 \mathrm{~m}$. Length-frequency modes identified by modal analysis corresponded closely with mean lengths of fish based on otolith annuli counts, supporting the hypothesis that the number of annuli corresponds to the age of the fish. The otolith length was linearly correlated with the fish length. An opaque annulus was deposited over a short period, primarily August. The study indicated that $75-100 \%$ of the annual growth was achieved during the June-September period. Maximum life span was estimated to be 12 years. The parameters of the von Bertalanffy growth equation were: $\mathrm{K}$ $=0.24$ year $^{-1}, L_{\infty}=188.2 \mathrm{~mm}, \mathrm{t}_{\mathrm{o}}=-1.14$ year. The growth of the American sand lance in the study area was slower than for the same species and for $A$. dubius in more southern areas. The length-weight relationship indicated that the growth in weight was isometric and identical for both sexes. Length-weight relationship, gonadosomatic index and the observation of maturity stages suggested that reproduction takes place shortly after September. All the fishes were matured at 20 months of age. Males mature at a smaller size $(<85 \mathrm{~mm})$ than the females $(90 \mathrm{~mm})$.
\end{abstract}

\section{Introduction}

In the northwestern Atlantic, sand lances are distributed from Greenland to Cape Hatteras (Norcross et al., 1961; Nizinski et al., 1990). Two species of the genus Ammodytes cohabit in this region: $A$. americanus Dekay, 1842, the American sand lance, an inshore species found in shallow waters from Labrador to Delaware, and $A$. dubius, the northern sand lance, an offshore species found from Greenland to North-Carolina. The species can be discriminated on the basis of meristic and morphological characters (Meyer et al., 1979; Reay, 1970; Richards, 1982; Scott, 1972; Nizinski et al., 1990). Off the north shore of the Gulf of St. Lawrence, A. americanus is generally found over fine to very course bottom where it burrows at densities as high as 255 individuals per $\mathrm{m}^{2}$ (SaintPierre, MS 1985). The American sand lance fills a strategic niche in the marine ecosystem, acting as an important trophic link between secondary producers and a variety of fish, birds and mammals (Reay, 1970; Winters, 1983; Lock, 1987).

The north shore area of the Gulf of St. Lawrence is known for the presence of migratory birds and mammals and is an important fishing area. The possibilities of development of hydroelectric projects on outflowing rivers and the implementation of a National Marine Park in the region justify accumulating a good knowledge base of its ecosystem. Although the sand lance has been the subject of numerous studies in several geographical areas, no data have been published on $A$. americanus in the Gulf of St. Lawrence, and little information has been accumulated on its ecology. The present work describes the growth and the sexual maturation of this species off the north shore of the Gulf of St. Lawrence.

\section{Material and Methods}

Samples of $A$. americanus were collected on a monthly basis from June to September 1983 in an area between Riviere Saint-Jean and Longue Point, $64^{\circ} 00^{\prime}$ $64^{\circ} 21^{\prime} \mathrm{N}, 49^{\circ} 15^{\prime} \mathrm{W}$ (Fig. 1). Along the coast line they were captured at depths ranging from 1 to $40 \mathrm{~m}$ with a beach seine $(27 \mathrm{~m}$ long, $3.6 \mathrm{~m}$ high at its centre with a stretched knotless mesh of $1.3 \mathrm{~cm}$ in the codend), and a Van-Veen grab $\left(1 / 10 \mathrm{~m}^{2}\right)$ was also used to collect sand lance that had buried themselves.

The total length (tail lobes brought in line with the body) of every fish caught was measured to the nearest millimeter and subsamples (983 individuals, in total) were stored on ice and examined within 3 days after collection. On each subsampled fish, total length was measured to the nearest $\mathrm{mm}$ and total fresh weight taken to the nearest $\mathrm{g}$. Sexual maturity was determined using the scale defined by Cameron (MS 1958), as modified by Macer (1966). Seven stages of maturation considered were: 1 = immature, $2-5=$ development, 6 = spawning and $7=$ recovering (stages 1 and 7 may be difficult to distinguish). A gonadosomatic index was 


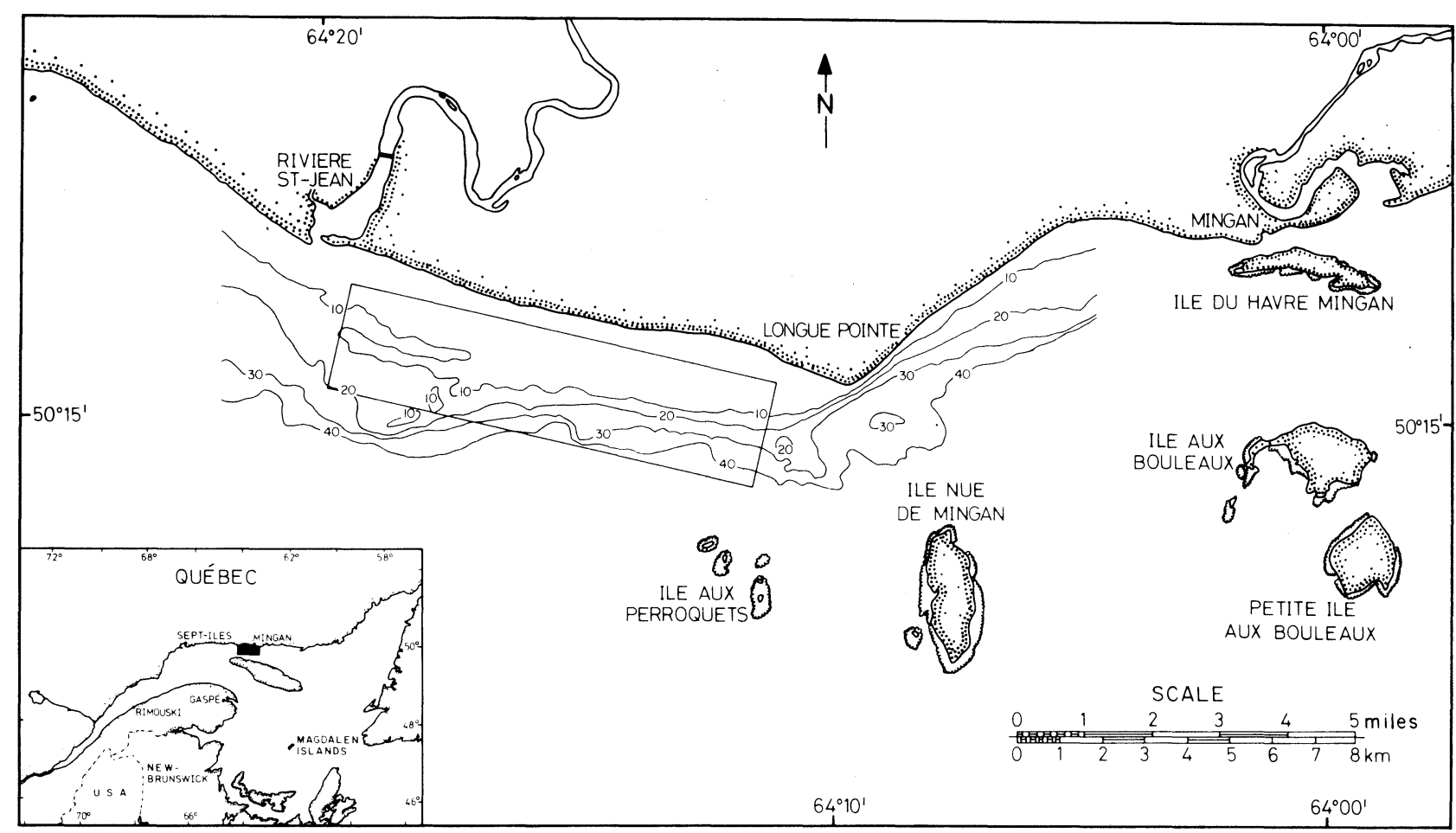

Fig. 1. Location of the study area off the north shore of the Gulf of St. Lawrence. Rectangle indicates sampled area. Depth contours are in meters.

calculated as the fresh weight of the gonad divided by the total fish weight.

In order to age the animals, otoliths were extracted and preserved dry; counting of annuli and measurements were done on the internal face of the left otoliths with these immersed in cedar oil and viewed under a binocular microscope. Maximum longitudinal length of the otolith was measured with a calibrated scaled ocular at $25 \times$ magnification. Of the otoliths examined, 847 could be interpreted. According to Reay (1972) and Scott (1973), each pair of hyaline and opaque annuli can be considered to correspond to one year in the age of the fish. Annular counts were done by only one reader. This single interpretation of the otoliths could have possibly been biased, but the bias was likely to be constant and trends observed were considered to represent the actual trends in the growth of the fish. The date of birth was arbitrarily set as the 1 January (Holden and Raitt, 1974).

An age-length key was used to calculate numbers at each length and age in the total sample from the aged subsample (Table 1). The proportions of hyaline and opague otolith edge types during the sampling period was recorded to examine the schedule of deposition of otolith rings. Mean lengths-at-age based on otolith readings were compared with length-frequency modes based on modal analysis to provide inferences on the validity of assigned ages. Lengths were grouped by $5-\mathrm{mm}$ classes, and the distributions obtained were decomposed following the maximum likelihood technique described by Macdonald and Pitcher (1979), using the computer software MIX (Macdonald and Green, 1988). Growth was expressed with the von Bertalanffy (1938) equation:

$$
L_{t}=L_{\infty}\left[1-e^{-k\left(t-t_{0}\right)}\right]
$$

where $L_{t}=$ the mean length-at-age $t$ (years), $L_{\infty}=$ the asymptotic length, $\mathrm{K}$ a constant defining the rate of change in length increments and $t_{0}$ a theoretical age for $L_{t}=0$. The von Bertalanffy model is widely accepted as a growth model for fishes (Gulland, 1969; Ricker, 1980). The growth curve was fitted using the iterative method proposed by Allen (1966) and by the linear regression technique proposed by Stamatopoulos and Caddy (1989) using the computer software CAST provided by those authors. The weight-length relationship fitted was:

$$
\log W_{t}=\log a+b \log L_{t}
$$

where $W_{t}=$ the weight $(g)$ at age $t$ and $L_{t}$ the corresponding length $(\mathrm{mm})$.

\section{Results}

Otolith maximum length was linearly related to the fish length ( $r^{2}=0.90$, Fig. 2). Deposition of opaque material occurred during the summer (Fig. 3). In June only $1 \%$ of the otoliths showed an opaque margin, but this percentage increased to reach a maximum in August $(84.7 \%)$. The trend was the same for both males 
TABLE 1. Age-length correspondence for the total catch (number fished) of Ammodytes americanus obtained from otolith readings of a subsample (number observed).

\begin{tabular}{|c|c|c|c|c|c|c|c|c|c|c|c|c|c|c|c|c|c|c|c|c|c|c|c|c|c|c|c|c|c|c|c|c|c|c|}
\hline \multirow{2}{*}{$\begin{array}{l}\text { Length } \\
(\mathrm{mm})\end{array}$} & \multicolumn{32}{|c|}{ Age (months) } & \multirow{2}{*}{$\begin{array}{l}\text { No. } \\
\text { fished }\end{array}$} & \multirow{2}{*}{$\begin{array}{c}\text { No. } \\
\text { observed }\end{array}$} \\
\hline & 9 & 18 & 19 & 20 & 21 & 30 & 31 & 32 & 33 & 42 & 43 & 44 & 45 & 54 & 55 & 56 & 57 & 66 & 67 & 68 & 69 & 78 & 79 & 80 & 81 & 90 & 91 & 92 & 93 & 103 & 104 & $\overline{114+}$ & & \\
\hline 60 & 2 & 20 & 1 & & & & & & & & & & & & & & & & & & & & & & & & & & & & & & 23 & 5 \\
\hline 65 & 2 & 46 & 10 & & & & & & & & & & & & & & & & & & & & & & & & & & & & & & 58 & 22 \\
\hline 70. & 1 & 106 & 17 & & & & & & & & & & & & & & & & & & & & & & & & & & & & & & 124 & 28 \\
\hline 75 & & 84 & 22 & 11 & & & & & & & & & & & & & & & & & & & & & & & & & & & & & 117 & 35 \\
\hline 80 & & 126 & 20 & 43 & & & & & & & & & & & & & & & & & & & & & & & & & & & & & 189 & 55 \\
\hline 85 & & 190 & 26 & 52 & 3 & & 5 & & & & & & & & & & & & & & & & & & & & & & & & & & 276 & 58 \\
\hline 90 & & 174 & 17 & 48 & 9 & 29 & 4 & & & & & & & & & & & & & & & & & & & & & & & & & & 281 & 67 \\
\hline 95 & & 128 & 11 & 46 & 4 & 18 & 2 & & & & & & & & & & & & & & & & & & & & & & & & & & 209 & 48 \\
\hline 100 & & 68 & 10 & 27 & 9 & 10 & 6 & & 1 & 10 & & & 1 & & & & & & & & & & & & & & & & & & & & 142 & 50 \\
\hline 105 & & 26 & 8 & 8 & 12 & 22 & 10 & 1 & & & 3 & 1 & & & 1 & 1 & & & & & & & & & & & & & & & & & 93 & 55 \\
\hline 110 & & & 3 & 2 & 4 & 32 & 3 & 2 & 2 & 16 & 5 & 2 & 1 & & & & & & & & & & & & & & & & & & & & 72 & 33 \\
\hline 115 & & 7 & 5 & 2 & 5 & 37 & 4 & 3 & 1 & 27 & 1 & & 1 & 10 & 1 & 1 & & & & & & & & & & & & & & & & & 105 & 46 \\
\hline 120 & & 1 & & & 1 & 4 & 2 & & & 12 & 6 & 3 & & 8 & 4 & 1 & & & & & & & 1 & & & & & & & & & & 43 & 36 \\
\hline 125 & & & & & & 5 & & & 4 & 23 & 3 & 1 & 2 & 11 & 1 & 1 & 1 & & & & & 2 & & & & & & & & & & & 54 & 38 \\
\hline 130 & & & & & & & & & & 8 & 5 & & 2 & 3 & 5 & & & 2 & 1 & 1 & & & & & & & & & & & & & 27 & 27 \\
\hline 135 & & & & & & 4 & & & 2 & 16 & & 3 & 2 & 10 & 2 & & 2 & 4 & 4 & 1 & 3 & & 1 & 1 & & & & & & & & & 55 & 38 \\
\hline 140 & & & & & & & & & & 3 & 2 & & 1 & 8 & 7 & 4 & 3 & 5 & 3 & 1 & 1 & & 1 & & & & & & & & 1 & & 40 & 36 \\
\hline 145 & & & & & & & & & & & 1 & & 2 & 4 & 3 & 2 & 3 & 2 & 3 & & & 1 & & & 1 & & 2 & 1 & & & & & 25 & 25 \\
\hline 150 & & & & & & 1 & & & & 1 & & & & 4 & 3 & & 1 & 1 & 2 & 1 & 1 & & 2 & 4 & 2 & 1 & 1 & 1 & & & & & 26 & 25 \\
\hline 155 & & & & & & & & & & & & & & & 5 & 2 & 2 & 1 & 5 & 1 & 2 & 3 & 3 & 2 & 1 & & 1 & 1 & & & 1 & & 30 & 29 \\
\hline 160 & & & & & & & & & & & & & 1 & 1 & 4 & & & & 3 & 3 & 5 & & 4 & 5 & 2 & 4 & & 1 & & & & & 32 & 26 \\
\hline 165 & & & & & & & & & & & 1 & & & 2 & & 1 & 1 & 1 & 2 & 1 & 1 & & 3 & 4 & 2 & 1 & 1 & 1 & & 1 & 3 & 2 & 28 & 28 \\
\hline 170 & & & & & & & & & & & & & & 1 & & 1 & & 1 & 1 & 1 & 2 & & 1 & 3 & & & 2 & & 2 & & 1 & & 15 & 14 \\
\hline 175 & & & & & & & & & & & & & & & & & & & & & & & 1 & 1 & 2 & 1 & 1 & & & 1 & 2 & & 9 & 8 \\
\hline 180 & & & & & & & & & & & & & & & & & & & 1 & & & 2 & & & & & & & & & 3 & 2 & 8 & 7 \\
\hline $185+$ & & & & & & & & & & & & & & & & & & 1 & 2 & & & 1 & & & & & & 1 & & 1 & & 2 & 8 & 8 \\
\hline
\end{tabular}

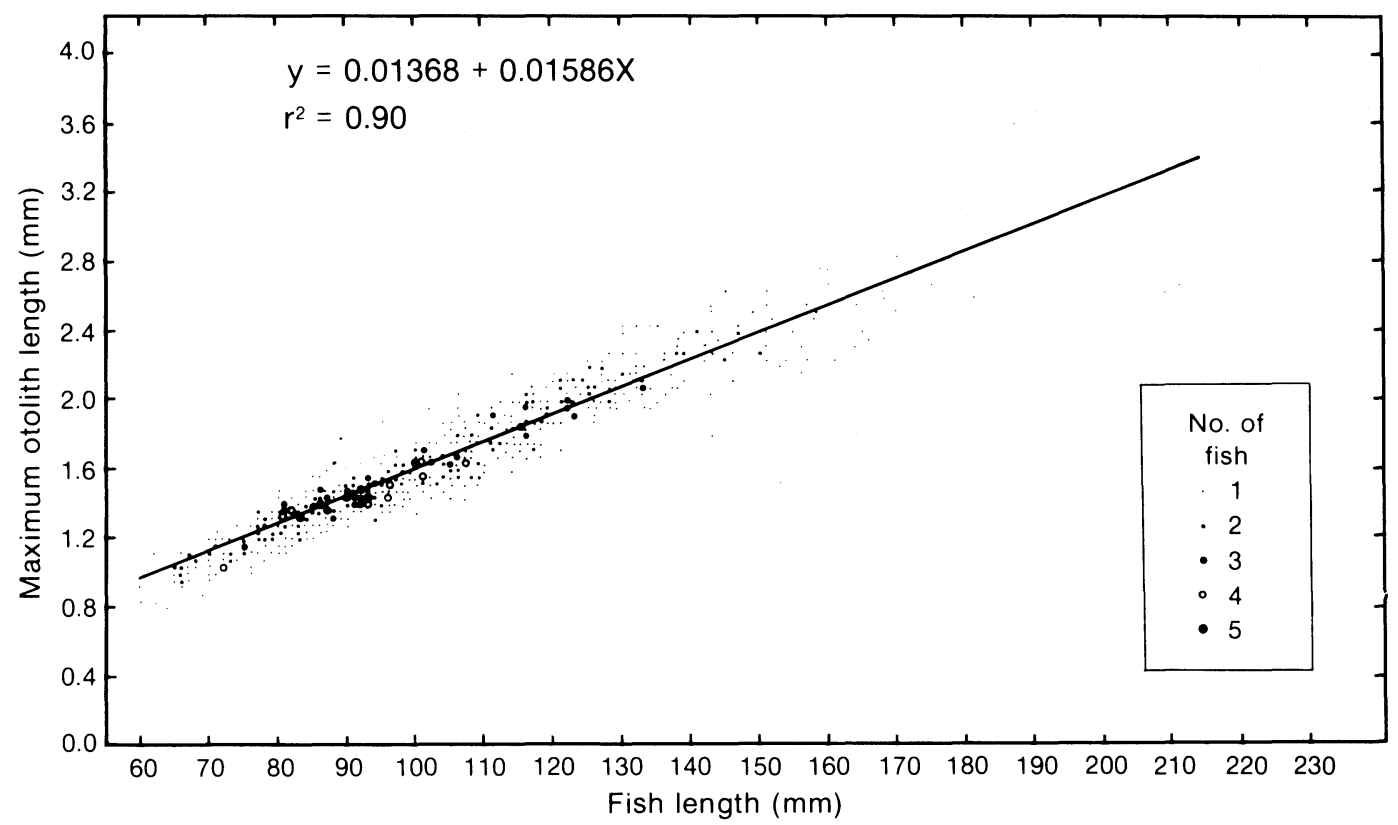

Fig. 2. Relations between the maximum length of the otolith and the total fish length of Ammodytes americanus.

and females with a sharp peak in deposition in August, while for immature animals there was a longer period of deposition of opaque material which lasted from July to September.

Modal analysis using the maximum likelihood technique provided a good fitting of the lengthfrequency distributions calculated by the technique to the actual observed ones, as confirmed by the Chisquare test for June $\left(X^{2}=12.4, P=0.72\right)$, July $\left(\chi^{2}=\right.$ 5.35, $P=0.95)$ and September $\left(\chi^{2}=3.70, P=0.93\right)$ samples. Sample size was too small in August to allow a useful analysis to be conducted. This analysis provided length modes which corresponded well with mean lengths calculated from otoliths (Fig. 4), particularly for June and July when sample sizes were large. A younger 


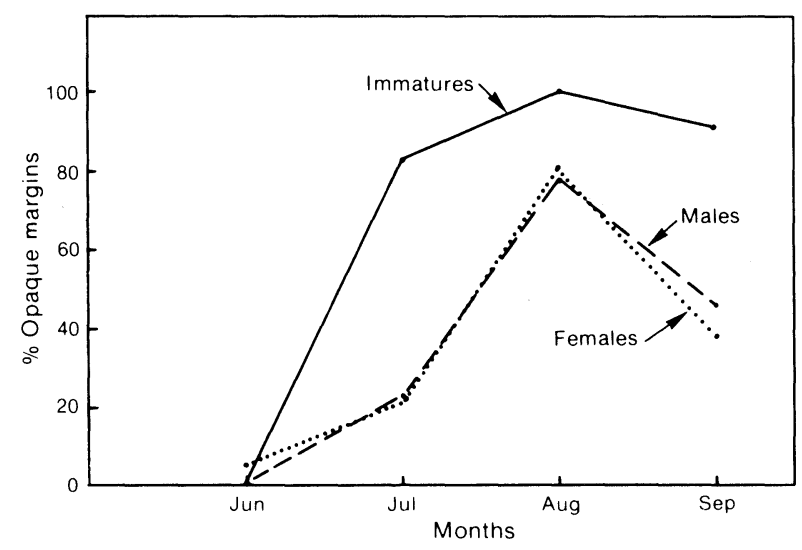

Fig. 3. Percentage of opaque margins on the otolith of Ammodytes americanus in each month by sex for mature specimens and for immature specimen.

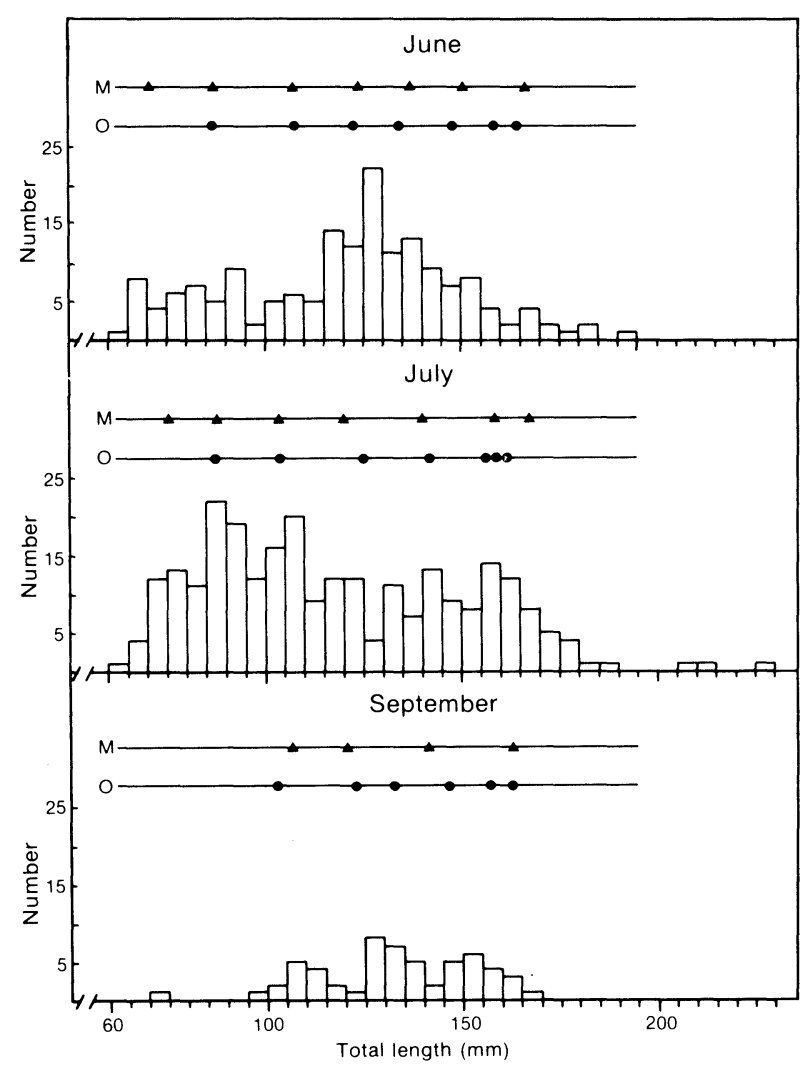

Fig. 4. Length frequency distributions of Ammodytes americanus and mean sizes of age groups defined by otoliths $(O)$ and modes determined by decomposition of the length frequency distributions $(M)$.

class, than detected by the otoliths, appeared in June and July, and some inconsistencies appeared for the oldest age groups.

An indirect validation of the ageing technique was provided by comparison, for a particular age group, of the length increase during the summer (i.e. length-atage $t$ in June and in September) and the length increase during 1 year (i.e. the length-at-age $t$ and the length-atage $t+1$ in June). Despite possible annual variations in growth, the increase during the summer was between 75 and $100 \%$ of the annual increase (Table 2 ). Thus the hypothesis that an opaque ring is laid down in the otoliths annually may be satisfied. The maximum age based on otolith readings was approximately 12 years (153 months).

The von Bertalanffy growth equation was calculated for the age groups containing more than five individuals. In order to use the Allen method and the Stamatopoulos and Caddy method, age was expressed in fractions of years. The parameters of the von Bertalanffy equation provided by both techniques gave similar results (Table 3 ).

The weight-length relationship was calculated separately for males and females and for the sexes combined, for each month (Table 4). A covariance analysis indicated that the differences between sexes was generally not significant, except for the slope in September (Table 5). The same analysis indicated significant variations between months (slope: $F=11.27$, DOF $=3,826, P_{F}<0.001$; position: $F=97.01$, DOF $=$ $\left.3,826, P_{F}<0.001\right)$. The slope of the length-weight relationship, b, was always close to 3 , which indicated an isometric growth for $A$. americanus. The growth in weight during the June-September period was slightly

TABLE 2. Comparison of the length increase of Ammodytes americanus during the study period and over a year.

\begin{tabular}{|c|c|c|c|c|c|}
\hline $\begin{array}{c}\text { Age } \\
\text { group }\end{array}$ & $\begin{array}{c}\text { Mean length } \\
\text { (June) } \\
\text { (mm) }\end{array}$ & $\begin{array}{c}\text { Mean length } \\
\text { (September) } \\
(\mathrm{mm})\end{array}$ & $\begin{array}{c}\text { Summer } \\
\text { increase } \\
(\mathrm{s} \%)\end{array}$ & $\begin{array}{c}\text { Annual } \\
\text { increase } \\
(a \%)\end{array}$ & $\begin{array}{l}\mathrm{s} / \mathrm{a} \\
(\%)\end{array}$ \\
\hline \multirow[t]{2}{*}{1} & 86.9 & 103.4 & 19.0 & & \\
\hline & & & & 25.1 & 75.7 \\
\hline \multirow[t]{2}{*}{2} & 108.7 & 123.0 & 14.3 & & \\
\hline & & & & 13.2 & $(101.4)$ \\
\hline \multirow[t]{2}{*}{3} & 122.8 & 132.9 & 8.2 & & \\
\hline & & & & 9.2 & 89.1 \\
\hline \multirow[t]{2}{*}{4} & 134.1 & 146.8 & 9.5 & & \\
\hline & & & & 10.6 & 89.6 \\
\hline \multirow[t]{2}{*}{5} & 148.3 & 156.5 & 5.5 & & \\
\hline & & & & 6.9 & 79.7 \\
\hline \multirow[t]{2}{*}{6} & 158.6 & 162.5 & 2.5 & & \\
\hline & & & & 3.3 & 75.8 \\
\hline 7 & 163.9 & - & - & & \\
\hline
\end{tabular}

TABLE 3. Parameters of the von Bertalanffy growth equation for Ammodytes americanus obtained by (a) the method of Allen (1966) and (b) the method of Stamatopoulos and Caddy (1989).

\begin{tabular}{ccc}
\hline & $\mathrm{a}$ & $\mathrm{b}$ \\
\hline $\mathrm{K} \mathrm{yr}^{-1}$ & $0.24 \pm 0.016$ & 0.24 \\
$\mathrm{t}_{\mathrm{yr}}$ & $-1.14 \pm 0.14$ & $-1.11 \pm 0.19$ \\
$\mathrm{~L} \mathrm{~mm}$ & $188.2 \pm 3.3$ & $188.1 \pm 0.2$ \\
Residual s $^{2}$ & 16.50 & 16.00 \\
\hline
\end{tabular}


TABLE 4. Weight-length relationship from a log-log linear regression observed for Ammodytes americanus $\left(r^{2}=\right.$ square of the correlaton coefficient; SEE = standard error of the estimate; SEI = standard error of the intercept; SES = standard error of the slope.)

\begin{tabular}{lcccccc}
\hline \hline Month & $\mathrm{r}^{2}$ & SEE & Intercept & SEI & Slope & SES \\
\hline & \multicolumn{5}{c}{ Male } \\
Jun & 0.956 & 0.038 & -5.397 & 0.188 & 2.895 & 0.089 \\
Jul & 0.956 & 0.054 & -5.689 & 0.179 & 3.032 & 0.085 \\
Aug & 0.940 & 0.088 & -5.869 & 0.195 & 3.157 & 0.093 \\
Sep & 0.960 & 0.054 & -5.095 & 0.161 & 2.787 & 0.077 \\
& & & Female & & & \\
& & & & & & \\
Jun & 0.938 & 0.048 & -5.374 & 0.204 & 2.878 & 0.096 \\
Jul & 0.944 & 0.056 & -5.575 & 0.192 & 2.972 & 0.091 \\
Aug & 0.940 & 0.088 & -5.869 & 0.195 & 3.157 & 0.093 \\
Sep & 0.949 & 0.067 & -5.693 & 0.212 & 3.062 & 0.100 \\
& & & & & & \\
& & & Total & & & \\
Jun & 0.969 & 0.063 & -5.894 & 0.072 & 3.118 & 0.035 \\
Jul & 0.980 & 0.051 & -5.608 & 0.055 & 2.990 & 0.027 \\
Aug & 0.968 & 0.069 & -6.125 & 0.085 & 3.272 & 0.042 \\
Sep & 0.960 & 0.065 & -5.655 & 0.119 & 3.046 & 0.056
\end{tabular}

TABLE 5. Results of the covariance analysis between weight-length relationships (log-log regression) of male and female Ammodytes americanus for each month.

\begin{tabular}{lcccc}
\hline \hline & $F$ & DF & $F_{0.05}$ & Significant \\
\hline & & June & & \\
$\begin{array}{l}\text { Position } \\
\text { Slope }\end{array}$ & 1.98 & 1109 & 3.9 & No \\
& 0.01 & July & & \\
$\begin{array}{l}\text { Position } \\
\text { Slope }\end{array}$ & 1.68 & 1122 & 3.9 & No \\
& 0.23 & & & No \\
$\begin{array}{l}\text { Position } \\
\text { Slope }\end{array}$ & 1.71 & 1158 & 3.9 & No \\
& 0.36 & & & No \\
$\begin{array}{l}\text { Position } \\
\text { Slope }\end{array}$ & 2.91 & 1106 & 3.9 & No \\
\hline
\end{tabular}

different between sizes. The expected weight, computed from the equation, of small individuals increased regularly over the season, while the expected weight of larger fishes decreased in September (Fig. 5).

The percentage of gonads at stages 5 and 6 (prespawning and spawning) rose from almost zero in June and July to $25 \%$ in August and $82 \%$ in September (Fig. $6)$. This trend was parallel to the gonadosomatic index which reached, for both sexes, a value close to $15 \%$ in September. The gonadosomatic index was lower for females than for males. The low percentage of stage 7 (postspawning), $1 \%$, indicated that reproduction had not yet started during the sampling period. Size and

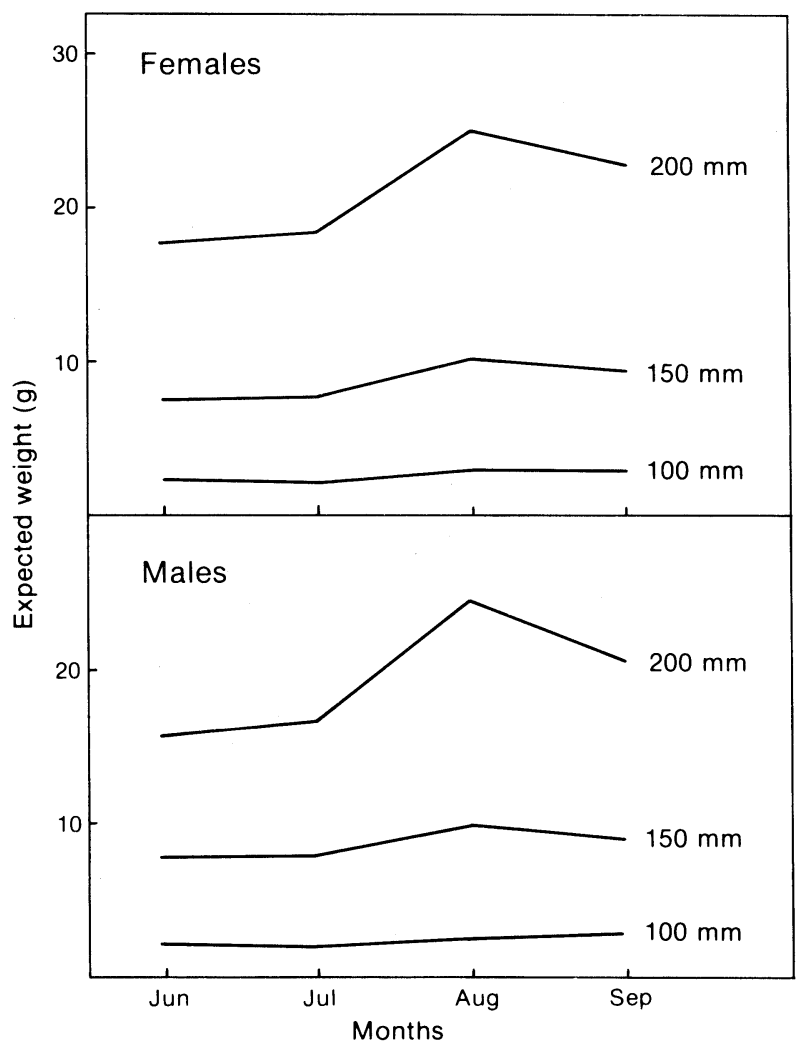

Fig. 5. Variation of the expected weight of three sizes of Ammodytes americanus in each month for individual males and females as defined from the weight-length relationship.

age at sexual maturity was determined from the August and September samples (322 individuals). Fifty percent of the fishes observed were still immature, with identifiable sex or not, at $95 \mathrm{~mm}$ length (Fig. 7). Among the individuals with an identifiable sex, $50 \%$ of the females were mature at $90 \mathrm{~mm}$, while, for the males, $83 \%$ were mature at $85 \mathrm{~mm}$ and no mature male was observed at a smaller length. The youngest mature fish was a female at age $0(69 \mathrm{~mm})$. Among the total of fishes observed in September, $72 \%$ were mature at age 1 (20 months) and $100 \%$ at age 2 . All the identifiable males (21 specimens) and $72 \%$ of the identifiable females (18 specimens) were mature at age 1 . In the whole sampling season (June-September), $67 \%$ of the identifiable males (65 specimens) were mature at age 1 and $84 \%$ (25 specimens) at age 2, $60 \%$ of the identifiable females ( 82 specimens) were mature at age 1 and $89 \%$ (28 specimens) at age 2.

\section{Discussion}

The present study is limited by its short duration of 4 months. However, the results are coherent with those of previous studies of the genus Ammodytes. The deposition of opaque material on the margin of the otolith during the summer months was noted in several 


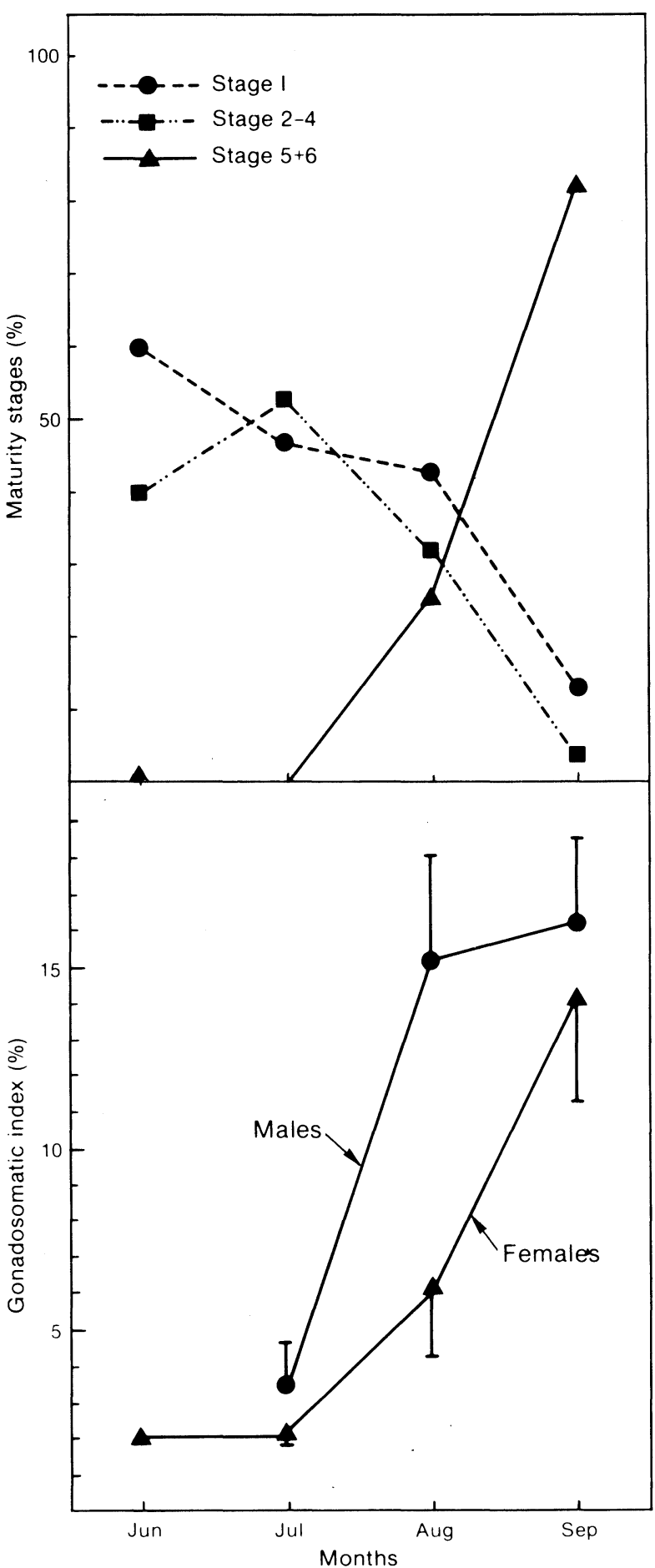

Fig. 6. Percentage occurrence of the maturity stages (sexes grouped), and the gonadosomatic index by sex for Ammodytes americanus in each month sampled. Vertical bars indicate the confidence interval at 0.95 probability level (only one half of the bar is presented for clarity).

previous studies. Cameron (MS 1958), studying the Ammodytidae of the Isle of Man, concluded that opaque material deposition occurred from March to October. Scott (1973) associated the hyaline zone with

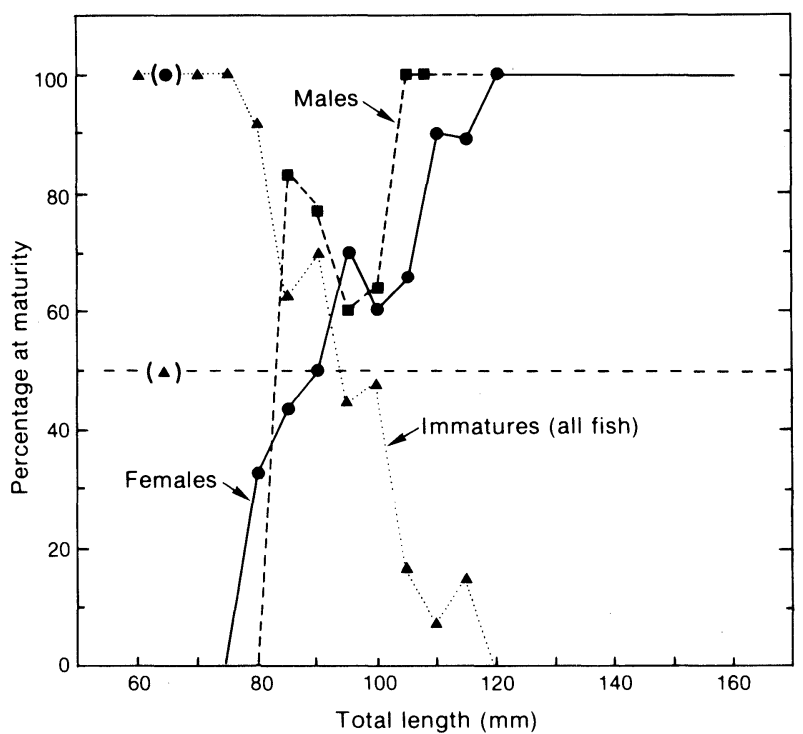

Fig. 7. Percentage of Ammodytes americanus at sexual maturity as the function of the total length in the months of August and September grouped. Percentage of immatures is based on all observations at length whether or not sex was identifiable, whereas percentage of matures by sex is based only on fish for which sex was identifiable.

the winter and the opaque zone with the summer growth period. The present results indicate that the opaque material deposition occurred briefly between July and September, when somatic growth is fast. The deposition period appeared to be related to the increase of the surface water temperature, which was $3.5^{\circ} \mathrm{C}$ in June, $4.0^{\circ} \mathrm{C}$ in July, $10.0^{\circ} \mathrm{C}$ in August and $7.5^{\circ} \mathrm{C}$ in September, during the study period (SaintPierre, MS 1985). In general, due to the Labrador Current, the surface temperature of the area remains low all through the year, increasing from about $0^{\circ} \mathrm{C}$ in April to $12^{\circ} \mathrm{C}$ in July-August, and decreasing to $3^{\circ}$ to $4^{\circ} \mathrm{C}$ in November (Weiler and Keeley, 1980). The deposition period lasted longer for immature than for mature fishes, possibly due to the fact that a large part of the energy of mature animals is devoted to the development of sexual products. There was a close linear relationship between otolith size and the length of the fish. Despite the fact that this relationship is curvilinear for most species (Reay, 1972), linear relations have already been observed by Westin et al. (1979) for A. americanus, Reay (1972) for $A$. tobiãnus, Macer (1966) for $A$. marinus, and Scott (1973) for A. dubius.

Ageing of the fishes using otoliths and length frequencies gave coherent results over much of the age range. A young age group (a "group 0" relative to the age group 1 observed with the otoliths) was recognized in the length frequency analysis. This may have been due to the difficulty observing the annual rings in otoliths before age 2 (Winters, 1983). Also, there were some inconsistencies for the oldest age group, which may have been due to the length frequency analysis technique being unable to discriminate efficiently the 


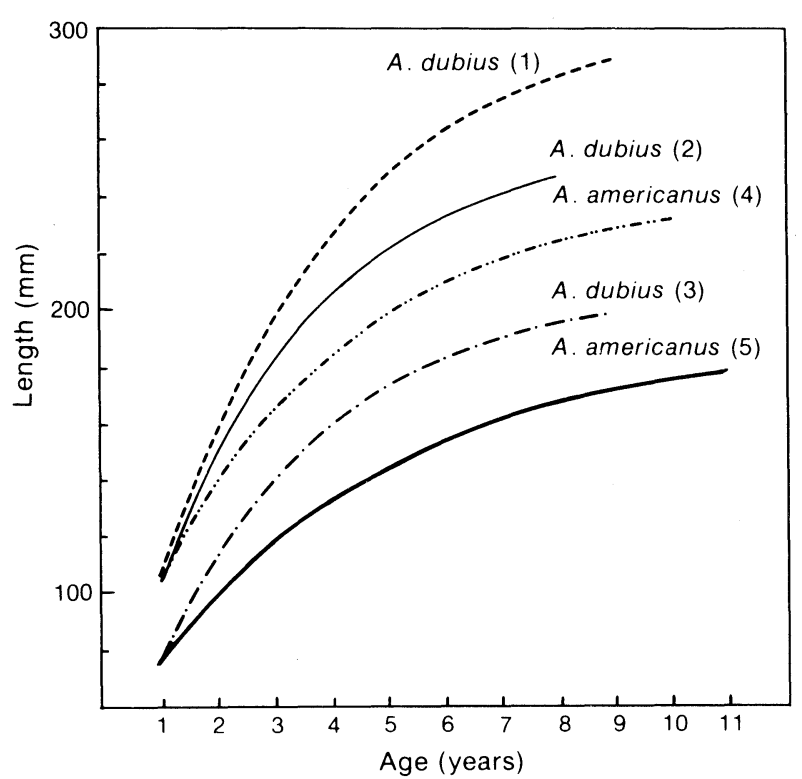

Fig. 8. A comparison of the growth curve for Ammodytes americanus obtained in this study with published growth curves for A. americanus and $A$. dubius from other areas: (1) A. dubius Western-Emerald banks (Scott, 1973); (2) A. dubius Grand Bank (Winters, 1981); (3) A. dubius Banquereau Bank (Scott, 1973); (4) A. americanus Merrimack River (Pellegrini, MS 1976); (5) A. americanus present study.

old age groups in the asymptotic part of the growth curve. Errors may also occur in the interpretation of otoliths for fish older than 7 years (Winters, 1983). The von Bertalanffy growth curve was calculated for the ages where the two techniques produced close results. A comparison of present results with published growth curves for this species and for A. dubius in the Northwest Atlantic (Fig. 8) shows that A. americanus from the north shore of the Gulf of St. Lawrence has a slower growth than the more southern Merrimack River population of $A$. americanus (Pelligrini, MS 1976), and of the populations of $A$. dubius on the Scotian Shelf (Scott, 1973) and the Grand Banks (Winters, 1981). Winters (1983) demonstrated a significant relationship between water temperature and the growth of $A$. dubius between ages 2 and 7 . The water temperature in the study area is low, reaching a maximum of $10^{\circ} \mathrm{C}$ in August, which could explain, to some extent, the low growth rate observed in the study area. The present results indicate that at least $75 \%$ of the annual growth occurs between June and September. A similar observation was made by Cameron (MS 1958) who noted little or no growth of A. tobianus and A. marinus, around the Isle of Man, between October and March. This is also consistent with the results of Macer (1966) on A.tobianus, on the English coast, and on $A$. marinus, in the southern part of the North Sea.

The maximum observed life span was 12 years in the study area. This unusual observation may be due to a reading error. However, Winters (1983) observed $A$. dubius older than 10 years on the Newfoundland Grand Bank, which may indicate that a greater lifespan is associated with low growth rate.

This study period did not cover the reproduction period. The trends observed for the maturation of the gonads, for the gonadosomatic index and the somatic growth, which decreased slightly in September, indicate that the reproduction period had not yet started. Richards and Kendall (1973) observed that the sand lances located between the latitudes $35^{\circ} \mathrm{N}$ and $41^{\circ} \mathrm{N}$ have a long spawning period lasting from November to March. Richards (1982) noted that the American sand lance reproduces between December and April with a peak in December-January. Off the Magdalen Islands (Gulf of St. Lawrence), Saint-Pierre (MS 1985) observed $11 \%$ of fishes in a postspawning stage in November. The presence of some animals at this stage in September of the north shore of the Gulf of St. Lawrence may suggest that the reproduction takes place at the end of the autumn, between October and December.

The lengths of the smallest mature male and female were 85 and $69 \mathrm{~mm}$, respectively. The percentage of mature individuals indicate, however, that males mature at a slightly smaller size $(<85 \mathrm{~mm})$ than do the females $(90 \mathrm{~mm})$. However, the inclusion of immature fish for which sex cannot be identified gives a larger size at maturity for sexes combined of $95 \mathrm{~mm}$. This indicates that the estimates based on sexed fish only are biased downwards. These sizes are in close agreement with results published by other authors. Hashimoto and Kawasaki (1981) noted a minimal size of $84 \mathrm{~mm}$ for the females of $A$. personatus, in Japan, and Richards (1982) of $89 \mathrm{~mm}$ for $A$. americanus. Observations from the north shore of the Gulf of St. Lawrence indicates that maturation may occasionally occur at the end of the first year of life but that almost all fishes are able to reproduce at the end of their second year of life, which is in agreement with the work of Macer (1966) for the same species. Early maturation is not unusual for the genus Ammodytes. Macer (1966) observed few mature individuals of $A$. marinus before age 1 with lengths of $100 \mathrm{~mm}$. The same observation was made by Reay (1973) for A. tobianus. Observations on A. americanus off the north shore of the Gulf of St. Lawrence in this study are limited by the fact that the complete reproductive cycle was not observed. A more comprehensive study should be conducted in order to get a complete perspective of the ecology of this species in this particular geographic area.

\section{Acknowledgements}

The study was funded by the FCAR Team Program of the Ministère de l'enseignement supérieur, de la science et de la technologie of Quebec. The first and 
last authors also received grants from the Natural Science and Engineering Research Council of Canada.

\section{References}

ALLEN, K. R. 1966. A method of fitting growth curves of the von Bertalanffy type to observed data. J. Fish. Res. Board Can., 23: 163-179.

CAMERON, J. MS 1958. Studies on the Ammodytidae of the Isle of Man waters. Ph.D. Thesis, University of Liverpool, $198 \mathrm{p}$.

GULLAND, J. A. 1969. Manual des méthodes d'évaluation des stocks d'animaux aquatiques. Première partie: analyse des populations. Manuel FAO des sciences halieutiques, 4: $160 \mathrm{p}$.

HASHIMOTO, H., AND T. KAWASAKI. 1981. Population studies of the sandeel, Ammodytes personatus Girard, in Sendai bay and its neighbourhood. Tohoku J. Agric. Res., 31(4): 173-197

HOLDEN, M. J., and D. F. S. RAITT. 1974. Manuel des sciences halieutiques. Partie II: methodes de recherche sur les ressources et leurs applications. FAO Tech. Doc., 115: $223 p$.

LOCK, A. R. 1987. Recent increases in the breeding population of black-legged kittiwakes, Rissa tridactyla, in Nova Scotia. Can. Field-Nat., 101(3): 331-334.

MACDONALD, P. D. M., and P. E. J. GREEN. 1988. User's guide to program MIX: an iterative program for fitting mixtures of distributions (version 2.3). Ichthus Data Systems, Hamilton (Ontario), Canada, $60 \mathrm{p}$.

MACDONALD, P. D. M., and T. J. PITCHER. 1979. Age groups from size frequency data: a versatile and efficient method of analyzing distributions mixtures. J. Fish. Res. Board Can., 36: 987-1001.

MACER, C. T. 1966. Sand eels (Ammodytidae) in the southwestern North Sea; their biology and fisheries. Fish. Invest. Lond., Ser. II, 24(6): 55 p.

MEYER, T. L., R. A. COOPER, and R. W. LANGTON. 1979. Relative abundance, behaviour and food habits of the American sand lance, Ammodytes americanus, from the Gulf of Maine. Fish. Bull. U.S., $77(1)$ : 243-253.

NIZINSKI, M. S., B. B. COLLETTE, and B. B. WASHINGTON 1990. Separation of two species of sand lances, Ammodytes americanus and $A$. dubius, in the western North Atlantic. Fish. Bull. U.S., 88: 241-255.

NORCROSS, J. J., W. H. MASSMAN, and E. B. JOSEPH. 1961. Investigations of inner continental shelf waters off lower Chesapeake Bay, Part 2, Sand Lance larvae, Ammodytes americanus. Chesapeake Sci., 2(1-2): 46-49.

PELLEGRINI, R. H. MS 1976. Aspects of the biology of the American sand lance, Ammodytes americanus, from the lower Merrimack River estuary. Massachusetts Master's
Degree Problem, Univ. of Massachusetts, $44 \mathrm{p}$.

REAY, P. J. 1970. Synopsis of biological data on North Atlantic sand eels of the genus Ammodytes, ( $A$. tobianus, $A$. dubius, $A$. americanus and $A$. marinus). FAO Fish. Synop., 82(1): $1-8$.

1972. The seasonal pattern of otolith growth and its application to back-calculation studies in Ammodytes tobianus. ICES J. Cons., 34: 485-504.

1973. Some aspects of the biology of the sandeel, Ammodytes tobianus L., in Longstone Harbour, Hampshire. J. Mar. Biol. Assoc. U.K., 53: 325-346.

RICHARDS, S. W. 1982. Aspects of the biology of Ammodytes americanus from the St. Lawrence River to the Chesapeake Bay, 1972-1975, including a comparison of the Long-Island Sound post-larvae with Ammodytes dubius. J. Northw. Atl. Fish. Sci., 3: 93-104.

RICHARDS, S. W., and A. W. KENDALL, Jr. 1973. Distribution of sand lance, Ammodytes sp., larvae on the continental shelf from Cape Cod to Cape Hatteras from R. V. Dolphin surveys in 1966. Fish. Bull. U.S., 71: 371-386.

RICKER, W. E. 1980. Calcul et interpretation des statistiques biologiques des populations de poissons. Bull. Fish. Res. Board Can., 191F: 409 p.

SAINT-PIERRE, R. MS 1985. Écologie et biologie du lançon d'Amerique Ammodytes americanus Dekay 1842, sur le delta subtidal de la riviere Saint-Jean (Moyenne Cote Nord), Québec. Mémoire de Maîtrise, Universite du Québec à Rimouski (Québec, Canada), $190 \mathrm{p}$.

SCOTT, J. S. 1972. Morphological and meristic variation in Northwest Atlantic sand lances (Ammodytes). J. Fish. Res. Board Can., 29: 1673-1678.

1973. Otolith structure and growth in northern sand lance, Ammodytes dubius, from the Scotian Shelf. ICNAF Res. Bull., 10: 107-115.

STAMATOPOULOS, C., and J. F. CADDY. 1989. Estimation of the von Bertalanffy growth parameters: A versatile linear regression approach. ICES J. Cons., 45: 200-208.

von BERTALANFFY, L. 1938. A quantitative theory of organic growth. Human Bio., 10: 181-213.

WEILER, J. D. M., and J. R. KEELEY. 1980. Monthly temperature surface temperature for the Gulf of St. Lawrence. Mar. Environ. Data. Serv. Tech. Rep., 7: $47 \mathrm{pp}$.

WESTIN, D. T., K. J. ABERNETHY, L. E. MELLER, and B. A. ROGERS. 1979. Some aspects of the biology of the American sand lance, Ammodytes americanus. Trans. Amer. Fish. Soc., 108: 328-331.

WINTERS, G. H. 1981. Growth patterns in sand lance, Ammodytes dubius, from the Grand Bank. Can. J. Fish. Aquat. Sci., 38: 841-846.

1983. Analysis of the biological and demographic parameters of the northern sand lance Ammodytes dubius, from the Newfoundland Grand Bank. Can. J. Fish. Aquat. Sci., 40: 409-419. 